\title{
可搬型観測プラットホームを用いた夏季仙台湾沿岸域における 水塊構造計測の試み
}

\author{
Measurements of vertical distributions of velocities and water qualities in Sendai sound in \\ summer using a mobile oceanographical observation platform
}

\author{
八木 宏 $^{1} \cdot$ 上原伸二 ${ }^{2} \cdot$ 中山哲嚴 ${ }^{3} \cdot$ 小川浩史 ${ }^{4} \cdot$ 中村哲也 $^{5} \cdot$ 足立久美子 $^{6}$ \\ Hiroshi YAGI, Shinji UEHARA, Akiyoshi NAKAYAMA, Hiroshi OGAWA \\ Tetsuya NAKAMURA and Kumiko ADACHI
}

\begin{abstract}
A mobile oceanographical observation platform, which can measure vertical distributions of water qualities of coastal water and velocities, has been developed in this study. This system was deployed $12 \mathrm{~km}$ off Abukuma river mouth in Sendai sound in summer of 2010. The observation results have shown the characteristic three layer structures; the surface layer with low salinity and high water temperature, the middle layer with the salinity maximum, high DO concentration and large mean diameter of SPM and the bottom layer with stable lower temperature and relative high Chlorophyll a. The comparisons of these vertical distributions with the results of water quality survey around Sendai sound and Jyoban coast have suggested that the three layer structure was generated by the intrusion of offshore saline water into the middle layer of Sendai sound.
\end{abstract}

\section{1.はじめに}

大陸棚海域は，排他的経済水域の貴重な再生産資源で ある水産資源を持続的に利用して行くために重要な海域 であり，現在，国の施策として人工海底山脈，保護育成 礁等の整備が進められつつあるが，陸棚海域の海洋環境 については未解明な点が多く，生産性の高い海域環境創 出のためのボトルネックとなっている．東京湾などの内 湾域では流速及び水質等の鉛直分布まで自動計測する体 制（モニタリングポスト）が整備されつつあるが，開放 的な沿岸域や陸棚海域ではこのような高度な計測システ ムやモニタリング体制がない。今後，海域環境の実態を 把握していくためには，水温・塩分等の詳細な鉛直分布 構造や近年現場型センサーで計測が可能となりつつある 栄養塩や懸濁物粒度組成など高度な情報を集積した形で 計測していくことが重要と考えられる.

そこで, 本研究では, 多項目水質量の鉛直分布の自動 計測が可能な可搬型観測プラットホームを製作し，それ を夏季仙台湾沿岸域に適用することで開放性沿岸域，陸 棚海域の水塊空間構造の把握を試みた。仙台湾は，開放

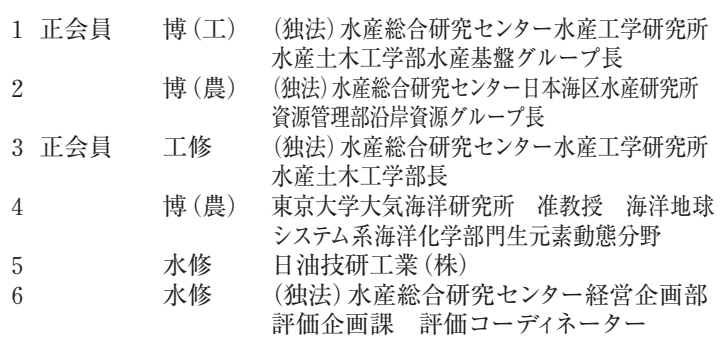

的な湾域であるが生産性が高く魚介類の豊富な海域とし て知られ，また最近では貧酸素水塊の発生が指摘（岩 井,2004）されているものの，海況や沿岸環境構造に関す る知見が少なく（海洋学会沿岸海洋部会：1985, 白石ら, 2008)，流動を含めた沿岸環境モニタリングの重要性が 指摘されている（上原・南，2008）.

\section{2. 可搬型観測プラットホーム及び現地観測の概要}

（1）可搬型観測プラットホーム

本研究では多項目水質量の鉛直分布計測が可能である 可搬型の観測プットホームを製作した（図-1）。本装置は 各種水質計を搭載した降昇部が海中を一定時間間隔で上 下移動し，また海底着底部にADCPや水質計を装着する ことで，流速や水質量の鉛直分布，底層水質量の時間変 動を計測することができる構造となっている．また本装 置は，船舶等を用いて実海域に比較的容易に設置・回収 ができるため観測タワーなど専用施設がない海域でも多
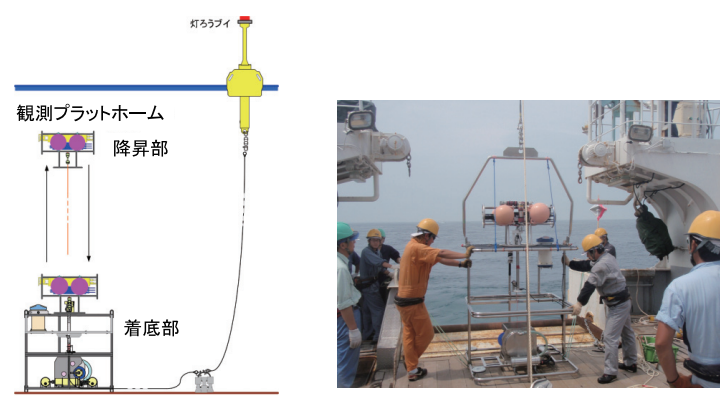

図-1 可搬型観測プラットホーム（左：設置概念図, 右：調查船による機器設置作業) 
表-1 可搬型観測プラットホームの基本性能

\begin{tabular}{c|c}
\hline 項目 & 内容 \\
\hline サイズ(着底部) & 縦 $120 \mathrm{~cm} \times$ 横 $120 \mathrm{~cm} \times$ 高 $150 \mathrm{~cm}$ \\
\hline 重量 $($ 着底部 $)$ & 空中 $150 \mathrm{~kg}$ 水中 $40 \mathrm{kgf}$ \\
\hline 降昇速度 & 上昇時 $: 15 \mathrm{~m} /$ 分, 下降時 $: 9 \mathrm{~m} /$ 分 \\
\hline 総降昇距離 & $40,000 \mathrm{~m}$ \\
\hline 降昇時間間隔 & 1回 $100 \mathrm{~m}$ の降昇距離の場合 200 回降昇可 \\
\hline
\end{tabular}

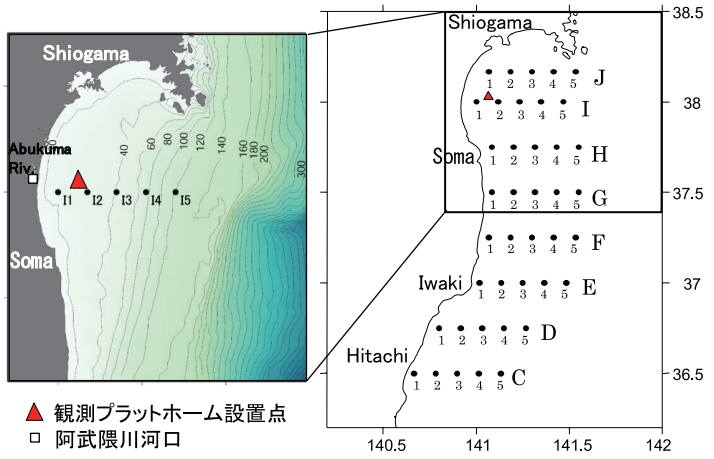

図-2 観測点の位置（左：観測プラットホーム設置点, 右：若鷹丸広域水質観測点)

項目水質量の連続的な鉛直分布計測が可能である. 本観 測プラットホームの基本性能を表-1に示す.

\section{(2) 現地観測の概要}

本観測プラットホームを用いた現地計測を仙台湾阿武 隈川河口沖 $12.5 \mathrm{~km}$ の地点（水深 $31 \mathrm{~m}$, 図-2参照）におい て実施した。観測プラットホームの設置回収は，東北区 水産研究所若鷹丸（平成 22 年度若鷹丸第 7 次航海ヒラメ 卵・仔稚魚調査，2010年7月 29日〜8月7日）によって 行い，7月31日に設置，8月7に回収し，その間の7日間 の連続計測を行った。観測項目は，降昇部による鉛直分 布計測については塩分・水温・DO ・ 濁度・クロロフィ ル蛍光光度・䀣濁物粒径分布・照度, 着底部における底 層連続計測では, 塩分・水温・DO · 濁度・クロロフィ ル蛍光光度であり, $\mathrm{ADCP} よ る$ 流速鉛直分布, 波高 · 波向計測を合わせて行った。ここで，懸濁物粒度分布は LISST-100X（Sequoia Scientific）, 波高・波向を含めた流 速鉛直分布計測にはWH-ADCPセンチネル $600 \mathrm{KHz}$ WAVE（RD-Instruments）をそれぞれ用いている.なお， 降昇観測については, 船の航行等による安全性を考慮し て海表面近傍を避け，海底上 $1.2 \mathrm{~m} \sim 27 \mathrm{~m}$ （水深 $30 \mathrm{~m} \sim$ $5 \mathrm{~m}$ 程度）を計測範囲として 1 時間に 1 回の頻度で観測を 行ったが，7日間の設置期間中のうち降昇部が安定して 上下移動をした7月 31 日 13:00〜8月3日8:00までの3日 間程度を解析対象とした。

また本観測期間中には若鷹丸によって，図-2に示した 仙台湾〜常磐海域の計 35 地点の観測点（観測線 $\mathrm{C} \sim \mathrm{J}$ )

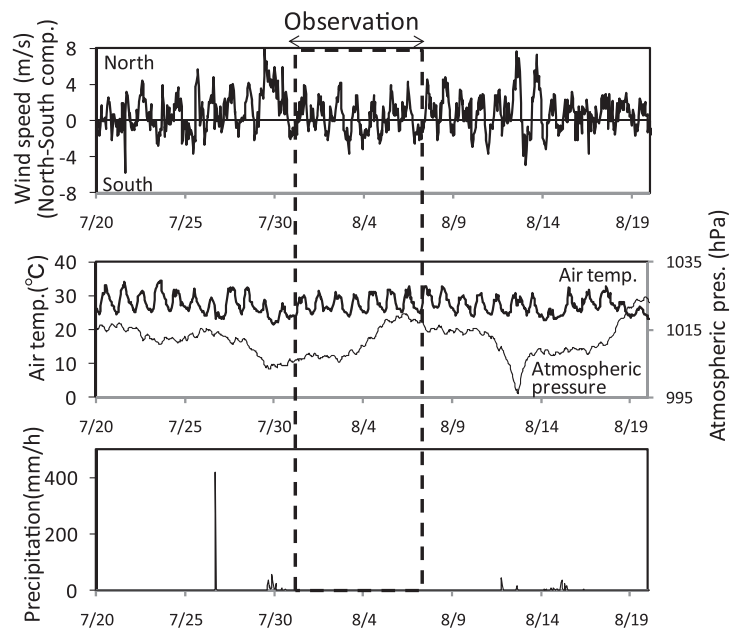

図-3 観測期間中の気象条件（風速南北成分：上段,

気温・気圧：中段，降水量：下段，仙台地方気象台）

において広域水質観測を実施しており，観測プラットホ 一ムの観測結果と合わせて水塊の空間構造特性の把握に 用いた。ささらに, 観測プラットホーム設置時, 撤収時, 観測点 $\mathrm{I} 1$ ～I5 の観測時には，各層採水（各地点 5 層程度） によるクロロフィル $\mathrm{a}$ 量, $\mathrm{SS}$, 栄養塩等 $\left(\mathrm{NO}_{3}, \mathrm{NO}_{2}, \mathrm{NH}_{4}\right.$, $\left.\mathrm{PO}_{4}, \mathrm{TP}, \mathrm{TN}\right)$, 瞅濁物質の炭素, 窒素の安定同位体比等 の計測も行った.

\section{（3）現地観測期間中の気象概況}

図-3に，仙台管区地方気象台の観測記録から観測期間 前後を含む 7 月 20 日から 8 月 20 日までの風速 (南北成分), 気温, 気圧, 降水量の時系列を示す. 観測プラットホー ムの設置期間は梅雨明け後の時期にあたり, 設置期間前 から期間前半にかけては低気圧や気圧の谷の影響により 天候がやや不安定であったが，期間後半は本州付近が高 気圧に覆われたため晴天となった。風系は，7月29日に 強い南風が吹き，その後も海陸風による日変動を伴いな がらも南風が卓越していた。

\section{3. 現地観測結果と考察}

（1）観測プラットホーム

a）底層水質量及び流速, 波高, 水深の計測結果

着底部に搭載した計測機器による観測結果を図-4に示 す.まず，水深及び波高の計測結果から観測期間は小潮 期から日潮不等の大きい大潮期に向かう時期であり，有 義波高は $1 \mathrm{~m}$ 程度と比較的静穏であったことがわかる. 一方, 底層（海底上 $1 \sim 1.2 \mathrm{~m}$ ）の水温・塩分は, 前半の 相対的に低温・低塩分の状態から8月 4 日前後で高温. 高塩分化しており, さらに底層のクロロフィル $\mathrm{a}$ 量につ いても日スケールの変動を伴いながら 8 月 4 日以降は低 下傾向を示している. このような底層水の変化は, 相対 


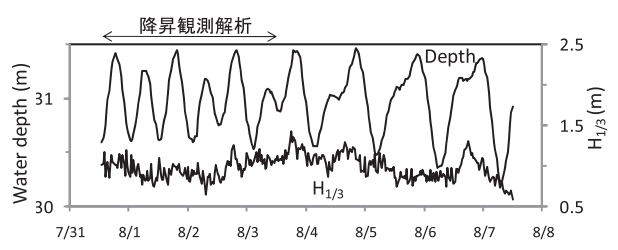

(a)水深及び有義波高

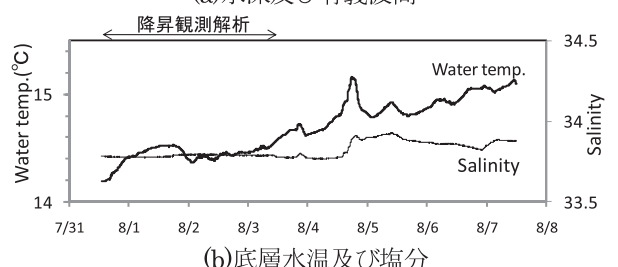

(b)底層水温及び塩分
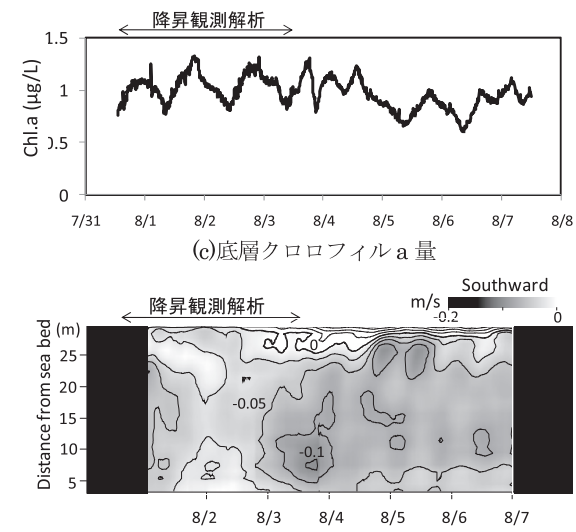

(d)残差流南北成分時空間コンター（南向き流速のみグレースケール）

図-4＼cjkstart観測プラットホームによる計測結果 I

(着底部搭載センサーによる計測)

的に高温・高塩分・低クロロフィル $\mathrm{a}$ 量の水塊が観測海 域に浸入したことを示唆している。図-4(d) には， $\mathrm{ADCP}$ の計測結果から残差流南北成分（25 時間移動平均 值）の時空間コンターを表示しているが，観測期間中盤 から後半にかけて中層以深で南向きの流れの残差流が卓 越しており，このような残差流と高温・高塩分水の浸入 との関係がうかがわれる. なお, 本研究では相対的に低 塩分・低温であった前半期間（図-4矢印）について，次 節以降で降昇観測及び若鷹丸による広域観測結果も合わ せ水塊特性の詳細な検討を行った。

\section{b）降昇観測による鉿直分布計測結果}

図-5に，降昇観測による水温，塩分，クロロフィル a 量, DO, 眯濁物質平均粒径の鉛直分布の時間変化を示 す。ここで懸濁物質の平均粒径は，レーザー粒度計 (LISST-100X) の計測結果から分画された各粒径サイズ をそれぞれの体積濃度で重み付き平均し算出している. まず，水温・塩分については，表層が高温・低塩分とな っており海底から $20 \sim 25 \mathrm{~m}$ （水深 7〜 $12 \mathrm{~m}$ ）付近に比較 的シャープな躍層が形成され，それが鉛直方向に振動し ている様子がわかる，振動の原因については，今後詳細

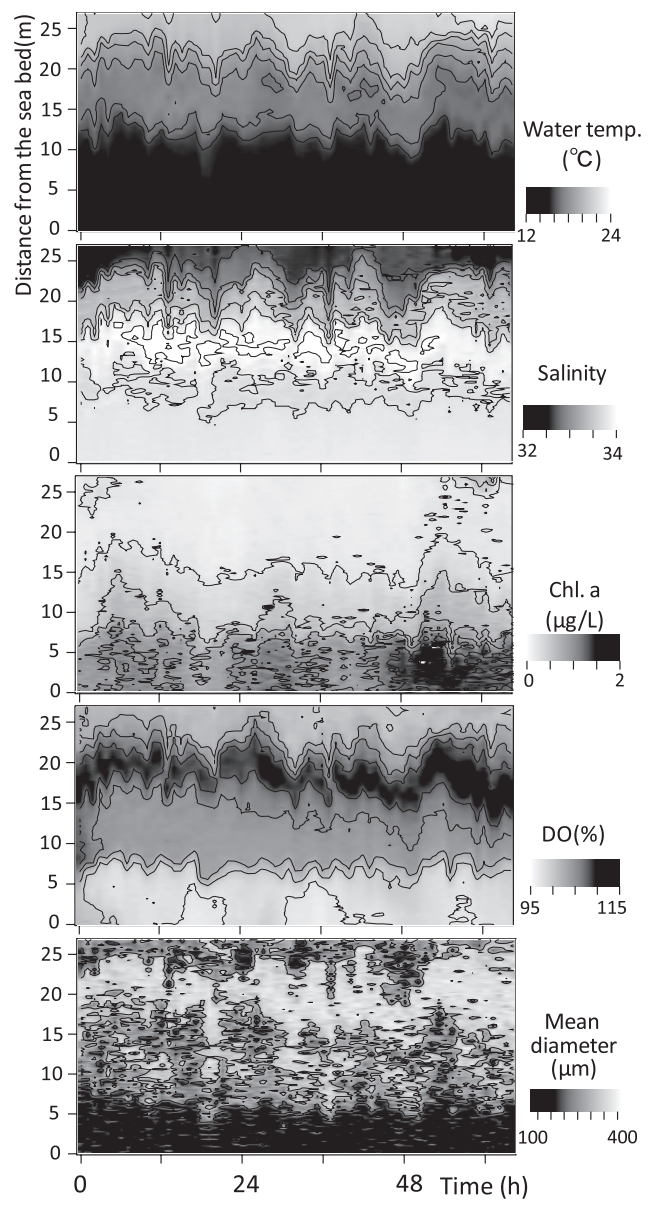

図-5 観測プラットホーム計測結果 II （降昇観測による各種 水質量の鉛直分布計測，7月31日 13:00 8月 3日 8:00)

な検討が必要だが，周期が半日程度であることから，仙 台湾陸棚縁辺に発生し沿岸に向かって伝播する半日周潮 の内部潮汐の影響が示唆される.ささらに層（海底上 8 〜 $18 \mathrm{~m}$ 程度）では高塩分のピークが生じその直下で塩分 が低下する塩分逆転が生じており，底層（海底上 $0 \sim 8 \mathrm{~m}$ 程度）では低温で塩分が比較的一様な水塊が分布する構 造となっている.

植物プランクトンの指標となるクロロフィル $\mathrm{a}$ 量につ いては，底層（海底上 $0 \sim 10 \mathrm{~m}$ 程度）で相対的に大きく なっており，ここでは結果は示さないが採水観測から得 られた栄養塩鉛直分布の傾向（底層で DIN， $\mathrm{PO}_{4}$ が増大） と整合したものとなっている。一方，DOについては全 体的に飽和度 $90 \%$ 以上であり貧酸素状態は見られない が, 特徴として中層（海底上 $8 \sim 22 \mathrm{~m}$ 程度）でDOレベル が高い（過飽和状態）ことが挙げられ，中層上端でピー クを示すような構造となっている.さらに眯濁物質の平 均粒径についても中層, 特に中層上部で平均粒径が大き 


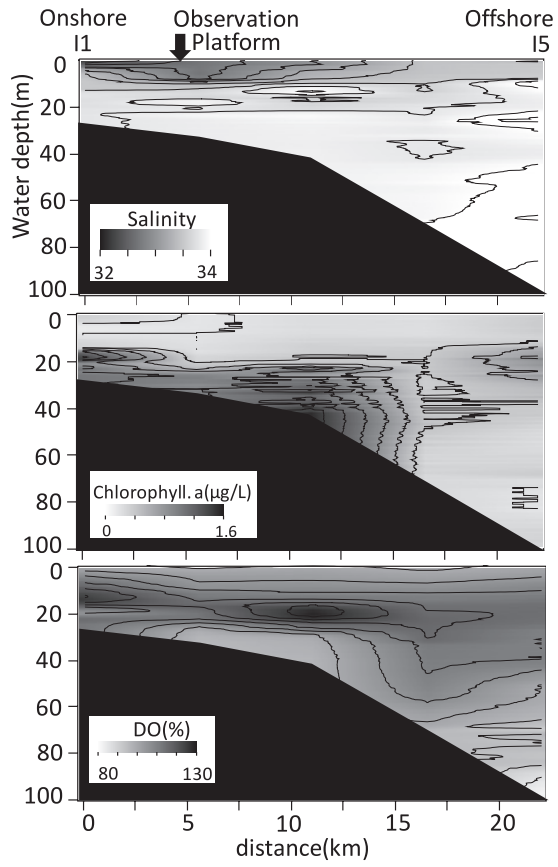

図-6 観測線Iにおける塩分，クロロフィル $\mathrm{a}$ 量, DOの東西 断面分布

く鉛直分布の傾向はDOと似ている.このような DO と懸 濁物質粒度組成の鉛直分布の傾向やその関係については 今後検討が必要であるが何らかの中層水の特徽を示唆し ているものと考えられる.

以上の計測結果から仙台湾阿武隈川河口沖の水塊鉛直 構造をまとめると, (1)高温・低塩分の表層, (2)高塩分ピ ークとその直下の塩分低下及び相対的に高 DO で懸濁物 平均粒径が大きい中層, (3)低温で塩分が比較的一様であ

り, クロロフィル $\mathrm{a}$ 量が大きい底層の 3 層構造となってお り，それが内部潮汐により周期的に上下に振動している ものと推定される.

\section{（2）若鷹丸による広域水質観測}

a）断面分布

図-5に示した仙台湾阿武隈川河口沖の水塊鉛直構造と 広域の水塊分布との関係を把握するために, 若鷹丸によ る広域水質観測の結果との関係を調べた。図-6は，観測 プラットホーム設置点に近い広域水質観測の観測線 I （図-2参照）に沿った塩分，クロロフィルa量，DOの東 西断面分布である。これを見ると，塩分は沖側の陸棚縁 辺部で高く, 陸棚域では表層で低塩分, 中層にはパッチ 状に塩分の高い水塊が薄く分布している. クロロフィル $\mathrm{a}$ 量は陸棚底層で相対的に高く, またDOは中層に濃度レ ベルの高い水塊が陸棚縁辺に近い海域から沿岸部まで広 く分布している.このような塩分, クロロフィル $\mathrm{a}$ 量,

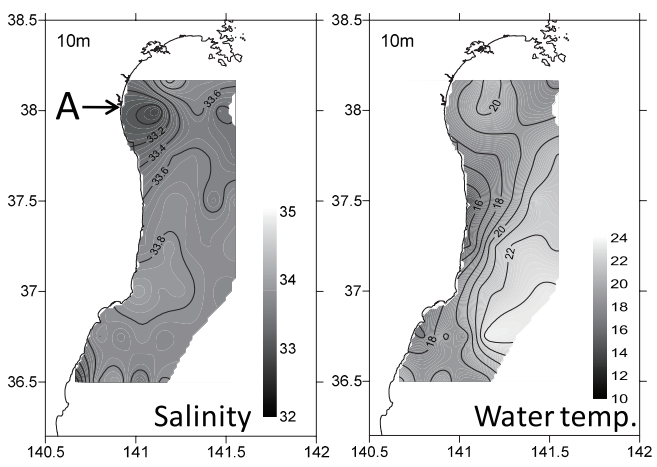

(a) $10 \mathrm{~m}$ 深

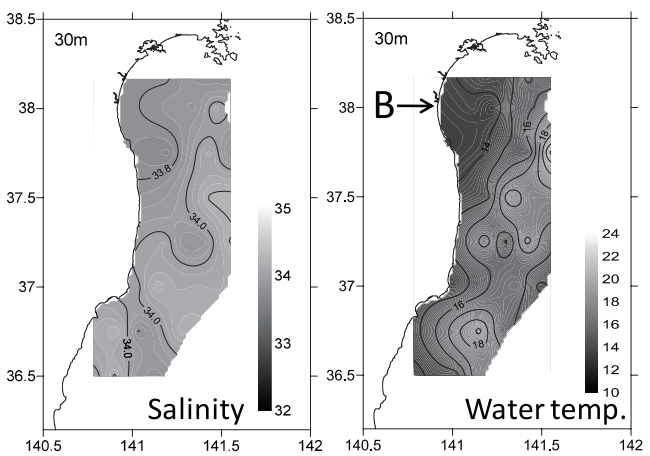

(b) $30 \mathrm{~m}$ 深

図-7 広域水質観測（若鷹丸）による $10 \mathrm{~m}$ 深及び $30 \mathrm{~m}$ 深の 塩分（左）・水温（右）の平面分布

DOの断面構造は, 先に示した観測プラットホーム設置 点での水塊鉛直構造とも整合している。

\section{b）平面分布}

次に，平面的な水塊構造との関係を把握するために仙 台湾〜常磐海域における $10 \mathrm{~m}$ 深及び $30 \mathrm{~m}$ 深（観測プラッ トホーム設置点の底層水深に相当）の水温及び塩分の平 面分布を図-7に示す. 基本的な特徵として, 沖側 (東側), 南側で黒潮系水の影響と思われる高塩分・高温の傾向が 現れている. 観測プラットホームを設置した仙台湾周辺 については，10m深には阿武隈川から流出したと思われ る低塩分水が拡がっており（図-7矢印 $\mathrm{A}$ ), また $30 \mathrm{~m}$ 深で は沖側より低温の水塊が仙台湾南部を中心に分布してい る (図-7矢印B)。これらは，観測プラットホームで計測 された水塊鉛直構造のうち表層の低塩分水塊と底層の低 温水塊にそれぞれ相当するものと考えられる。

\section{c）水塊特性}

次に，水塊特性を調べるために，プラットホーム設置 点近傍の観測点 $\mathrm{I}$ (水深 $31 \mathrm{~m}$ ), その沖側で陸棚縁辺部の 観測点 I5 (水深 $130 \mathrm{~m}$ ), やはり陸棚縁辺部でI5よりも南 側で相馬沖の観測点 H5 (180m) について塩分水温特性 を図-8に示した。図中には，参考としてHanawa \& Mitsudera （1987）による三陸海域における水塊区分を点 


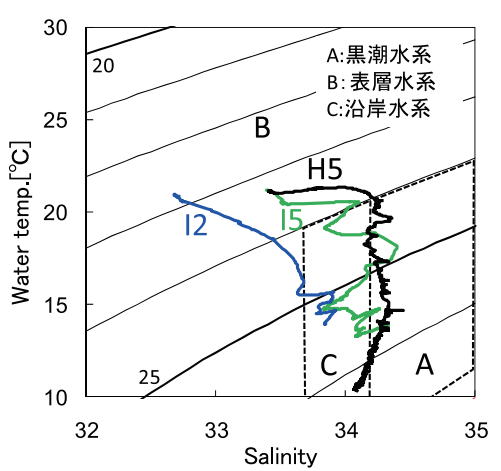

図-8 観測点I2,I5,H5における水塊特性

線で記入している。但し, Hanawa \& Mitsudera (1987) で津軽暖水系に区分される水塊については，本研究で対 象としている仙台湾〜常磐海域には津軽暖水系の直接的 な影響は少なく，むしろ黒潮系と親潮系もしくは表層水 との混合水が中心と考えられることから（白石ら,2008）, ここではこれをまとめて沿岸水系として表示している.

まず，沖合南側に位置する相馬沖の観測点 H5では, 表層を除くと全体的に高塩分・高温の傾向があり黒潮系 水の影響を強く受けていることがわかる。一方，観測プ ラットホーム設置点近傍の観測点I2では，上層では表層 水系，底層でも観測点 $\mathrm{H} 5$ と比較すると低塩分，同じ水 深帯で比べると低温の傾向があり，これは図-7に示した 仙台湾南部の $30 \mathrm{~m}$ 深帯（観測プラットホーム設置位置で は底層）に分布する低温・低塩分の沿岸水に相当する. これに対し，観測プラットホーム設置点沖の観測点I5で は，黒潮系水と沿岸水が上下に分布するような傾向があ り，両者が混在した特性となっている。さらに，図-9に は，観測線 Iよりも南側に位置する相馬沖観測線 $H$, その さらに南側の観測線 $\mathrm{G}$ に沿った塩分の東西断面分布を示 す.これを見ると，沖側から高塩分水が層状に陸棚域に 浸入し一部パッチ状に分布しており，これは観測線Iの 中層に見られた塩分分布と似た傾向である。

これらの観測結果は，仙台湾〜常磐沿岸に分布する沿 岸水とその沖側の黒潮系水が接する本海域では水平方向 に両水塊が層状の浸入を活発に生じさせていることを示 唆しており, 図-5の仙台湾阿武隈川河口沖の水塊鉛直構 造に現れた中層の特徴（塩分ピークと塩分逆転）は, こ のような黒潮系水の浸入及びその後の沿岸水との混合に よって形成されたものと推定され，それが3層の鉛直構 造が形成された原因と考えられる.

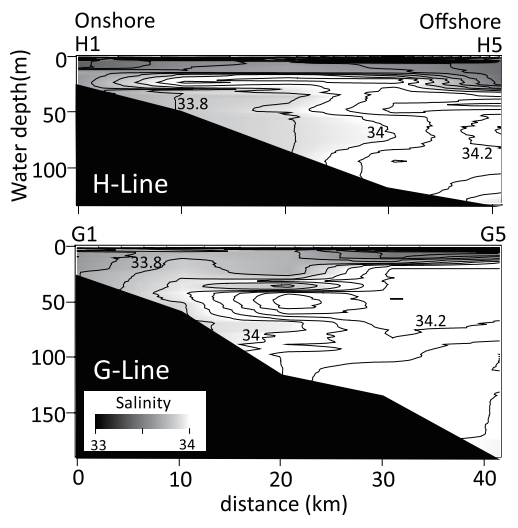

図-9＼cjkstart観測線H,Gに沿った塩分の東西断面分布

\section{4. まとめ}

水質量の鉛直分布計測を可能とする可搬型の観測プラ ットホームを製作し, それを夏季仙台湾沿岸域の水塊構 造計測に適用した。その結果，多項目水質量の連続的鉛 直分布計測に成功し，観測期間中の仙台湾沿岸域の水塊 鉛直構造の基本的な特徵とその内部潮汐による変動を示 した。また若鷹丸による広域水質観測結果から観測プラ ットホームで計測された水塊の鉛直 3 層構造が, 阿武獚 川河口からの低塩分表層水と陸棚下層に分布する低温水 の間に外海側から水塊が浸入・混合したことにより形成 された可能性を示した。

謝辞：本研究は科研費基盤研究 (B)「境界層計測プラット ホームを用いた陸棚海底環境の実態計測とモデル化」（代 表者：八木宏）等により行われた。 また観測を実施するに あたっては, 独立行政法人水産総合研究センター東北区水 産研究所若鷹丸の本間盛一前船長をはじめスタッフの方に ご協力頂いたことをここに記して謝意を表します.

\section{参 考 文 献}

岩井拓郎 (2004)：近年の仙台湾における貧酸素水発生状況と発 生要因の検討, 宮城水産技報, 第4号, pp.1-12.

上原伸二・南卓志 $(2008)$ : 仙台湾の環境と漁業 一沿岸域の底 魚資源を中心として一 浮遊期仔魚調査から, 水産環境研 究, 第 72 巻, 第 1 号, pp.55-56.

海洋学会沿岸海洋部会 (1985) : 第7章仙台湾 II 物理, 全国沿岸 海洋誌, pp.263-271.

白石一成・水島 宏·筧 茂穂 (2008): 仙台湾の環境と漁業 沿岸域の底魚資源を中心として一 定線海洋観測調査から, 水産環境研究, 第72巻, 第1号, pp.53-55.

Hanawa, K. and Mitsudera, H.(1987): Variation of water system distribution in the Sanriku coastal area, Journal of Oceanography Society Japan, 42, pp.435-446. 